\section{Research Article: Screening of safflower varieties / cultivars, genotypes and germplasm lines against Alternaria carthami}

\author{
S.S. WAGH, A.P. SURYAWANSHI AND V.M. GHOLVE
}

Article Chronicle: Received :

19.07.2017;

Accepted :

03.08.2017

KEY WoRds :

Germplasm,

Alternaria carthami,

Safflower, Resistance, Susceptible

Author for correspondence :

\section{S.S. WAGH}

Department of Plant Pathology, College of Agriculture, Vasantrao

Naikl Marathwada Krishi Vidyapeeth, PARBHANI (M.S.) INDIA

Email : drwaghss@gmail. com

See end of the article for authors' affiliations
SUMMARY : Safflower is one of the most important oilseed crop grown in India and there are several cultivars and verities are available but fragmented information available their reaction against pathogen particularly Alternaria blight (Alternaria carthami). There is the absolute need to screening under epiphytotic condition during the year 2013-14 and 2014-15. In the year 2013-14 total 36 test entries of safflower exhibited different reactions against A. carthami. However, three entries viz., HUS-305, DSH242 and A-1 showed tolerant reaction with mean blight intensity in the range of 18.64 to 24.64 per cent; 14 entries showed susceptible reaction with moderate mean blight intensity in the range of 26.47 to 50.25 per cent and 19 entries exhibited highly susceptible reaction with higher mean blight intensity in the range of 51.50 to 87.92 per cent. None of the safflower entry was found immune or resistant or moderately resistant to the disease. During 2014-15, 39 test entries of safflower exhibited different reactions. However, three entries viz., DSF-2014, PBNS-84 and PBNS-122 showed tolerant reaction with mean blight intensity in the range of 20.17 to 25.00 per cent; 25 entries showed susceptible reaction with moderate mean blight intensity in the range of 26.15 to 50.13 per cent and 11 entries exhibited highly susceptible reaction with higher mean blight intensity in the range of 56.50 to 85.15 per cent. None of the safflower entry was found immune or resistant or moderately resistant to the disease.

How to cite this article : Wagh, S.S., Suryawanshi, A.P. and Gholve, V.M. (2017). Screening of safflower varieties / cultivars, genotypes and germplasm lines against Alternaria carthami. Agric. Update, 12(TECHSEAR7) : 1965-1968; DOI: 10.15740/HAS/AU/12.TECHSEAR(7)2017/1965-1968. 